\title{
The changing politics of information in European foreign policy
}

Citation for published version (APA):

Dijkstra, H., \& Vanhoonacker, S. M. R. L. (2011). The changing politics of information in European foreign policy. Journal of European Integration, 33(5), 541-558. https://doi.org/10.1080/07036337.2010.546845

Document status and date:

Published: 31/01/2011

DOI:

10.1080/07036337.2010.546845

Document Version:

Accepted author manuscript (Peer reviewed / editorial board version)

Document license:

Unspecified

\section{Please check the document version of this publication:}

- A submitted manuscript is the version of the article upon submission and before peer-review. There can be important differences between the submitted version and the official published version of record.

People interested in the research are advised to contact the author for the final version of the publication, or visit the DOI to the publisher's website.

- The final author version and the galley proof are versions of the publication after peer review.

- The final published version features the final layout of the paper including the volume, issue and page numbers.

Link to publication

\footnotetext{
General rights rights.

- You may freely distribute the URL identifying the publication in the public portal. please follow below link for the End User Agreement:

www.umlib.nl/taverne-license

Take down policy

If you believe that this document breaches copyright please contact us at:

repository@maastrichtuniversity.nl

providing details and we will investigate your claim.
}

Copyright and moral rights for the publications made accessible in the public portal are retained by the authors and/or other copyright owners and it is a condition of accessing publications that users recognise and abide by the legal requirements associated with these

- Users may download and print one copy of any publication from the public portal for the purpose of private study or research.

- You may not further distribute the material or use it for any profit-making activity or commercial gain

If the publication is distributed under the terms of Article $25 \mathrm{fa}$ of the Dutch Copyright Act, indicated by the "Taverne" license above, 


\title{
The Changing Politics of Information in European Foreign Policy
}

\author{
2011
}

\author{
Hylke Dijkstra \& Sophie Vanhoonacker \\ Department of Political Science, Faculty of Arts and Social Sciences, \\ Maastricht University, The Netherlands
}

This is the final electronic version of an article published in: Journal of European Integration 33(5): 541-558

\begin{abstract}
This article studies the development of European foreign policy from an informational perspective. It illustrates how since the establishment of European Political Cooperation in 1970, the European Union has gradually evolved from a platform to share foreign policy information into a Brusselsbased system that gathers and processes information autonomously. Building upon the broader literature of delegation in international organisations, it explains the gradual shift in the centre of informational gravity from the national capitals to Brussels through motives of efficiency and credibility. The development of an operational foreign policy after the Treaty of Amsterdam has considerably raised the demands for rapid and high quality data. A system entirely dependent on the ad hoc information flows from the member states proved incompatible with these new ambitions. The recent establishment of the European External Action Service and the transformation of the European Commission delegations into Union delegations is the most recent step in this long-term and highly institutionalised process of European informational cooperation.
\end{abstract}

\section{Key words}

European Union, foreign policy, information, information-sharing, bureaucracy, decision-making

\section{Introduction}

Information is a key resource in public policy-making. Given that policy-making typically consists of assessing the anticipated payoffs of alternative courses of action, it is essential for political decision-makers to possess adequate and reliable information about the current state of affairs. This is particularly important in foreign policy (George 1980; Epstein and O'Halloran 1999). States thus have an incentive to optimise their information-gathering and processing capabilities and they have done so over the last centuries - without exception - through the establishment of ministries of foreign affairs and diplomatic services. It should be emphasised that the activities of collecting and analysing foreign policy information were, due to their sensitive nature, mostly limited to actions of states. Each state had its own apparatus resulting from the principle of 'self-help' in the international system. Information-sharing only occurred on an ad hoc and strategic basis and nonstate actors did not play a major role in the bilateral 'dialogue between states' (Watson 1982).

In the context of the European Union (EU), individual member states have changed their methods of gathering and processing information. Over the last 40 years, there has been an incremental institutionalisation of information-sharing with the result that information about foreign 
policy is now shared continuously in all major dossiers. More recently, the member states have also established various analytical bodies in Brussels that perform information-processing tasks autonomously in support of the common policies. These bureaucracies provide the member states with strategy papers, risk assessments, crisis management concepts, and draft common positions. Most of these analyses are still informed by input from the member states and open sources, yet the European bureaucracies are also increasingly engaged in information-gathering of their own. The creation of the European External Action Service (EEAS) and the transformation of the external delegations of the European Commission into Union delegations will further enhance these functions. This article explains why the EU has developed, over time, from a platform for sharing foreign policy information into a collector and processor of information in its own right.

Building upon the broader literature of delegation in international organisations, it argues that the ambition of the member states to develop an operational foreign policy has led them to go beyond information sharing. Driven by motives of efficiency and credibility, they have established European-level bodies for information-gathering and processing. Explaining why member states intensively share information and have delegated some of their information-gathering and processing is particularly relevant. After all, it is widely recognised that the possession of information empowers certain actors over others in the process of foreign policy-making (Downs and Rocke 1994; Milner 1997). Although the member states thus benefit from sharing information and from the support of Brussels-based bureaucracies analysing and gathering data, they are also increasingly losing control over foreign policy information.

This article fits in with a larger body of literature on the evolution of foreign policy-making in the context of the European Union. Similar contributions to date have focused on the formal division of competences between the national and European level or on the role of civil servants in Brussels (see Allen 1998; Müller-Brandeck-Bocquet 2002; Vanhoonacker, Dijkstra and Maurer 2010). Such approaches, however, ignore informal processes of policy-making or put too much emphasis on the EU rather than the European foreign policy system as a whole. ${ }^{1}$ They thus at best describe and measure activity indirectly. This article starts with explaining the role of information in foreign policy generally, before discussing the changing politics of information in European foreign policy in a chronological fashion.

\section{Information-Sharing and Information-Delegation in Foreign Policy}

Before discussing the role of information in foreign policy, it is important to provide some clarity on the terminology. This article focuses primarily on the processes of gathering and processing information, both of which have the aim of reducing the uncertainty of policy-makers when making and executing decisions regarding foreign policy (Warner 2002; Walsh 2006; Müller-Wille 2008). In this context it is important to note the following. First, foreign policy information differs from intelligence (which can be seen as a sub-category of information) in that it is neither necessarily secretive nor solely concerned with security issues. Second, given that states remain the key actors within the international system, most of the gathering and processing of information is done by states. Third, three important underlying assumptions must be made: (a) the future is uncertain and information can help to reduce such uncertainty, (b) foreign policy information is a scarce resource and not automatically available to all international actors, and (c) actors are 'boundedly rational', meaning that they have limited time and cognitive skills. Political leaders, when making and executing foreign policy decisions, therefore have to rely on supporting bureaucracies for the gathering and processing of information.

States gather their foreign policy information via three different channels: they have their own autonomous capabilities, they receive information from other international actors, and they use

1 European foreign policy is defined as the sum of what the EU and its member states do in terms of their 'political' foreign policy (Hill 1998). It excludes trade and development. 
publicly available sources (e.g., media, reports by think tanks and universities, and the internet). While the latter two channels are essential for day-to-day policy-making, and while individual politicians sometimes prefer to use such sources, various academic observers have empirically established that first-hand information collected by a state's own administration is usually more desirable (see Bull 1977; Watson 1982; Hocking 1999; Hill 2003). Given that survival is ultimately determined by strategic decisions, and these decisions rely on informational input, states are generally reluctant to 'outsource' their information-gathering capabilities — whether it is to other international actors or based on open sources. Instead, many states have established networks of foreign services so that they can collect their own information. ${ }^{2}$ Such services are, however, expensive; hence, their provision may come at the expense of other activities funded by the same national budget. The marginal costs and benefits of acquiring additional foreign policy information through autonomous channels must therefore be assessed. Costs help to explain why some states, usually those with more global interests and greater resources, maintain more extensive diplomatic services than others.

The information that is gathered subsequently needs to be processed. Just as foreign policy decision-makers (such as presidents, foreign ministers or under-secretaries) cannot collect all the relevant information themselves, neither do they have the time, the analytical capabilities, or expertise in foreign policy to analyse it (see George 1980; Vertzberger 1990). For analysis, they have supporting bureaucracies, such as foreign ministries in the capitals, at their disposal, just as they have networks of diplomatic services for gathering information (Watson 1982). It needs to be said, though, that although analytically the gathering and processing of information may usefully be separated, in practice there is not always a clear distinction between them. Individual ambassadors possess significant expertise and are generally already making analyses when writing diplomatic telegrams to their capitals. Civil servants in the foreign ministries may consult open sources directly without being in contact with the diplomatic posts, just as they may also be in direct contact with their counterparts in other states.

The high cost of autonomous information-gathering is a major incentive for states to engage in information-sharing. Even for large states the costs of autonomously collecting all foreign policy information are simply too high (Richelson 1990). States may also not have the opportunity to gather all the necessary input independently. For example, western countries face great difficulties in collecting human intelligence in the Middle East. They must therefore rely on local intelligence services (Betts 2002). Information-sharing, however, also has clear drawbacks. Trust is a necessary condition for the effective sharing of information (Walsh 2006). The risk that sources and methods may be compromised is ever present as is the chance that gathered information reaches third-party states. ${ }^{3}$ Providers of information, nonetheless, may have incentives to share their information, because it can affect the decisions or actions of the recipient in ways that benefits the sender. There is furthermore the issue of reciprocity in that sharing information engenders trust. This is particularly relevant, as Smith $(2004,91)$ put it, when states try to 'establish a common view of, and potential solution to, problems', which may explain the institutionalisation of information-sharing. Yet it needs to be stressed that eventually it is the sender of information that makes the cost-benefit analysis on whether information-sharing yields positive payoffs.

Since the sharing of information is often politically motivated, such information is senderbiased (Crawford and Sobel 1982), which makes it difficult to come to common views of problems, let alone solutions. If joint decisions and actions yield high mutual payoffs for states, they thus have to find ways to come to common analysis. One way is to delegate the task of informationprocessing to international organisations, which are due to their neutral reputation more credible in their analysis of the information (Abbott and Snidal 1998; Hawkins et al. 2006). Apart from the

2 Diplomatic posts also serve other purposes than information-gathering, but the collection of information constitutes a key function.

3 The recent Wikileaks affair only emphasises this point. 
credibility argument, having one centralized bureaucracy in charge of information-processing is also more efficient than the various national administrations processing independently. It not only reduces the number of required civil servants nationally, it also demands less coordination between states, which can be an obstacle when rapid response is required. Furthermore, giving the pen to one actor is more efficient than drafting documents with multiple member states in working groups. When solely delegating the task of information-processing while keeping information gathering 'inhouse', states remain in control of the information that flows into these organisations (Stone 2009).

There are also cases where states have delegated information-gathering tasks as well. This is particularly attractive when they are themselves not in a position to provide credible information by their own actions (e.g., inspections of nuclear facilities, election observation, monitoring implementation) (Keohane 1984; Hawkins et al. 2006; Milner and Moravcsik 2009). Furthermore neutrality and efficiency considerations are important. By delegating fact finding or technical assessment missions to international organisations, for example, the states that engage in joint decisions and actions receive relatively unbiased information at a lower cost than if they went to the region themselves. Examples of the need for efficiency are international peacekeeping operations, where the commander cannot wait for the contributing states to provide him/her with situation awareness and intelligence reports. Indeed, in such missions states delegate the responsibility of information-gathering, and regular reporting goes the other way around - from the mission to the contributing states via the respective international organisation. For national purposes, states may still keep their own channels open after delegating these tasks, but the international organisations are no longer solely dependant on states for their information.

When delegating the tasks of information-gathering and information-processing to international organisations, states necessarily have to balance the costs and the benefits of delegation. Delegation inevitably leads to agency losses and may empower those actors to whom the tasks have been delegated. In a classic principal-agent model, an informational surplus is indeed the most significant resource of the agent to whom tasks have been delegated (see Arrow 1985; Pollack 2003; Miller 2005). A common paradox thus arises, in which the sharing of information and the delegation of informational tasks to improve the quality of strategic decisions leads to a situation in which states are losing control over policy-making, with the international organization concerned becoming empowered. States anticipate this when delegating tasks of an informational nature and are thus reluctant to do so. Indeed, delegation might lead to sub-optimal situations from the viewpoint of efficiency, because as Stone $(2009,35)$ rightly notes 'it may be the case that principals would like to delegate more functions to international institutions, but do not do so because they cannot control the institution's policies'.

Before providing empirical evidence of how European foreign policy has developed from an informational perspective, a few general comments on the nature of the EU are required. First, while the EU is not a state, its member states collectively engage in joint decisions and action, for which they require foreign policy information. Second, European foreign policy remains largely driven by its member states. As a result, the 'centre of gravity' of information lies with the member states themselves. Nevertheless, the last 40 years have seen a gradual process whereby Brusselsbased players have become increasingly important. The establishment of the European External Action Service is the most recent step in this long process. Third, there are substantial differences between the foreign policies of individual member states, in that two are permanent members of the United Nations Security Council and possess nuclear weapons, some are formally neutral, some have a colonial past, and others had no significant foreign policy until they joined the EU. Clearly, this creates both opportunities and problems for sharing information.

\section{Sharing Information during European Political Cooperation (1970-1993)}

Following the Treaty of Westphalia (1648), states became the key actors in the international 
relations in Europe. Their diplomatic relations generally took place within a bilateral context. In an era, in which communication and travel were difficult and time-consuming, ambassadors and their staff were the gatekeepers of information gathered in third states. Information was processed in the offices of the foreign ministers and the heads of state and government (Watson 1982). Multilateral conferences such as the Congress of Vienna (1814-1815) were limited to the large states and focused on collective security (the prevention of hegemony) rather than the coordination or formulation of joint foreign policy (Kupchan and Kupchan 1991; Kissinger 1995). The League of Nations, resulting from Treaty of Versailles (1919), despite its own budget and civil servants, focussed on collective security as well. After the Second World War, the creation of lasting collective defence organisations or regional organisations (e.g., NATO, EU), where actual joint decisions vis-à-vis external actors are made, was therefore an important step in the history in international relations.

Although the European project was political in nature, its instruments were in the first place economic. Attempts at political integration, such as the European Defence Community (1950-1954) and de Gaulle's proposal for a Political Union (1960-1962), all failed, illustrating the highly sensitive character of any cooperation in the area of high politics (Hoffmann 1966; Bodenheimer 1967; Fursdon 1980). As the economic integration process proceeded in the context of the European Community, an external dimension developed through trade policies and relations with the former colonies of the member states. However, the lack of a forum for political consultation and information exchange became increasingly problematic. Instruments such as preferential trade agreements lend themselves very well for political purposes. As a result, there was a need to add a political element to the external economic relations of the European Community (de Schoutheete 1986). The heads of state and government of the six founding member states therefore asked their foreign ministers at the Hague summit (1969), only months after de Gaulle had left politics, 'to study the best way of achieving progress in the matter of political unification' (Final Communiqué).

Due to earlier failures and the sensitive character of political integration, cooperation in the field of external political relations was initially developed outside the legal umbrella of the European Community under the framework of European Political Cooperation (EPC). It was organised on a purely intergovernmental basis 'with a bare minimum of institutional support' (Smith 2004, 71). The European Commission, for example, initially only participated in dossiers that had a clear connection to Community affairs. It took until the 1980s before it was granted full access to the meetings. The weak role of the Commission together with the lack of a central secretariat gave a key position to the six-monthly rotating Presidency. The initial ambitions of EPC were similarly modest. One of its main objectives was to work towards the harmonisation of views and 'joint action when it appears feasible and desirable' (Luxembourg Report 1970). There was no blueprint for cooperation between states and EPC grew in a pragmatic and incremental way, reacting to the needs of the time. The development of standard operating procedures took place informally often being codified in a series of reports. It was only with the Single European Act (1987) that the coordination of foreign policy received a formal treaty base.

The limited ambitions of EPC made it in the first place a potential forum for informationsharing. The exchange of information and consultation amongst member states is mentioned in its founding document as its first objective. Ben Tonra $(2003,744)$ indeed notes that 'the raison d'etre of EPC and later [Common Foreign and Security Policy (CFSP)] deliberations was, of course, information'. The sharing of information was seen as the first step and a prerequisite for building a community of views and ultimately a community of action (de Schoutheete 1986). It would also allow states to profit from one another's areas of expertise and thus had particular value for smaller member states that possessed limited diplomatic resources. The sharing of information was not automatic. The individual member states determined what (not) to share and remained the gatekeepers of information. During EPC, there was no collective information-gathering nor was there a supranational European bureaucracy to analyse the material systematically. The entire 
process was in the hands of the member states and the rotating Presidency operating from the national capitals. They processed the available information and used it for the purpose of common declarations.

One of the reasons for the eventual success of information-sharing between member states was that this process was institutionalised from fairly early on (Smith 2004). In 1973, the member states decided to establish the so-called Correspondance Européenne (COREU) communication network, which allowed them and the European Commission to exchange enciphered messages (see Bicchi 2010). Each foreign ministry appointed one junior civil servant (European Correspondent) responsible for distributing the relevant information within the ministry and for sending it to the Permanent Representation of their country in Brussels. Information on practical organisational matters (e.g., invitations for meetings, agendas) as well as official diplomatic memorandums were transmitted via this system. By virtue of the continuous contacts facilitated by this system of communication, representatives of the member states could fine-tune common declarations and responses to parliamentary questions without having to meet in person (Nuttall 1992). Because the rotating Presidency was also in charge of all secretarial matters, the EPC archives moved to a different national capital every six months.

The sensitive nature of foreign policy coordination and the limited institutional support also affected the content and scope of the exchange of information. Initially only a limited number of dossiers were discussed in the context of EPC. The agenda was determined by contemporary developments, above all by the bipolar international system with questions on matters of security and defence during the Cold War being reserved exclusively for NATO. In the early days, member states devoted a great deal of time to the coordination of their positions for the Helsinki Conference on Cooperation and Security in Europe (CSCE). The energy crisis and the Yom Kippur War (1975) put the Middle East high on the agenda and triggered the Euro-Arab dialogue. As foreign policy coordination developed, the range of issues, and thus the topics on which information was shared, gradually expanded. The London Report (1981), for example, raised the possibility of dealing with questions related to 'the political aspects of security' within EPC. Questions of defence, however, remained beyond its scope.

In addition to the problem of scope, a second consequence of the lack of a blueprint for the sharing of information between member states was that the perspective of EPC was quintessentially short-term. Whenever there was a crisis in a non-EU country, the member states would exchange views and try to coordinate a reaction in the form of a common declaration or other diplomatic actions (e.g., démarches). Although the Copenhagen Report (1973) recommended medium and long-term studies, no such studies were undertaken. No single body was, after all, in charge of longterm policy development. There was no central secretariat and after each six-monthly Presidency was over, the leadership of EPC fell to another member state. Two initiatives of the British Presidency in 1977 and 1981 to establish a modest planning facility failed as a result of French concerns about sovereignty. Even after the Single European Act (1987) created a small-scale, though permanent, EPC secretariat in Brussels, the emphasis remained on short-term coordination. Reports, strategy papers and analyses based on shared information were thus not circulated. Simon Nuttall $(1992,77)$ concluded that 'planning has remained to this day one of the great lacunae in Political Co-operation'.

The member states' reluctance to cede sovereignty in matters of foreign policy meant that they tried to keep the European Commission at arms length. The informational advantage of the Commission in the field of external economic relations nevertheless allowed it to enter through the backdoor. In practice, it was difficult to distinguish between the external dimension of economic integration and foreign policy proper. The Helsinki Conference on the CSCE, for example, included an economic basket, which rendered the expertise of the Commission indispensable. The use of sanctions is another example that shows how member states depended on the Commission. Although decisions to impose restrictive measures were taken under EPC, eventually such measures 
had to be implemented by the European Commission. The importance of the expertise of the Commission was acknowledged in the Single European Act when it was made responsible, together with the Presidency, for the consistency of external relations. The flow of information also worked in the other direction: when formulating and implementing policies within the framework of the European Community, the Commission could profit from information on the political context supplied by the member states (ibid.).

A further characteristic of information-sharing under EPC was that it extended to the embassies of the member states in third countries and international organisations. These embassies formed a source of information for the member states and were often at the same time the channels through which EPC policies could be implemented. A decision attached to the Single European Act refers to the following areas of cooperation: the exchange of political and economic information, the pooling of information on administrative and practical problems, communications, security and consular questions, health, education, information and cultural affairs. ${ }^{4}$ It is furthermore interesting to note that the Commission participated in these meetings via its delegations. Again it was an important source of expertise on economic issues. Initially cooperation in third countries was slow. Progress again depended on the rotating presidency as chair of the meetings and on the number of member states that were represented in the third country. Nowadays, weekly meetings of Heads of Mission are common practice in many third countries.

During the first few decades of European foreign policy cooperation, member states mostly confined their activities to exchanges of information. The information transmitted through the COREU system and shared in various forums served in the first place to inform debates, and later found its way into declarations or political démarches. From an informational perspective, EPC was attractive in two ways. Firstly, the member states received access to new data and became part of a network well beyond that of their own diplomatic services. Given the different historical experience and geographical interests of the participants, the available expertise was considerable and much larger than most countries could acquire individually. With every enlargement round, the pool of data further expanded. Besides strengthened links between the national capitals, the diplomatic services in third countries also benefited from new information flows. Secondly, the system was set up in such a way that the national capitals remained the masters of the game. It was the member states who decided what to share with their partners. This was not without risk for those on the receiving end since information-sharing can be used strategically to steer decisions in a particular direction. This problem could have been circumvented by entrusting tasks of information gathering and processing to the EU institutions. For most member states however, this was a step too far. Since EPC was merely a declaratory policy the possible negative impact of sender-biased data remained limited.

EPC has often been dismissed as nothing more than a discussion forum. It was nonetheless an indispensable step for the further development of a more fully-fledged foreign policy. It not only created a habit of coordination but also contributed to the trust that was indispensable for more ambitious forms of informational cooperation.

\section{European Foreign Policy after the Cold War}

EPC was established during the Cold War, which determined to a large extent its foreign policy agenda. Not only were questions of defence addressed exclusively within the context of NATO, but the European states also had limited leeway in other areas since everything was seen through the lens of the bipolar balance. The situation changed after the fall of the Berlin wall, when international relations began to be influenced by factors other than the East-West divide. It was felt that Europe now had the opportunity to act on the international stage independently of the United States. This line of reasoning was not necessarily naive, because some of the most important issues

4 Decision adopted by the Foreign Ministers (17 February 1986). 
of the day required the close involvement of the EU. While Chancellor Kohl attempted to ignore the opinions of the other member states on German reunification, he had to talk with the European Commission on whether the former German Democratic Republic was complying with all the relevant European standards (Nuttall 2000). ${ }^{5}$ The end of the Cold War also meant that Western Europe had to renegotiate its relations with the Central and Eastern European countries on matters such as preferential trading, international aid and even future accession.

The break-up of former Yugoslavia also shows the nature of the involvement of the member states on matters of international significance. As this civil war (1991-1995) took place in Europe's backyard, the member states were closely involved with the various peace talks with the EU troïka, through the actions of the United Nations, but also through the EU administration in Mostar (19941996). ${ }^{6}$ While the member states were not successful in bringing the conflict to a close, the point is that questions of war and peace were now being discussed in Brussels. The events resulting from the end of the Cold War thus affected the scope of the European foreign policy. The Treaty of Maastricht (1993, see also below) also made clear reference to this fact in the creation of the CFSP, which included according to the preamble 'the eventual framing of a common defence policy', as a successor policy to EPC.

The increased scope and importance of the European foreign policy agenda after the Cold War was reflected in the intensity of the information exchange between the member states. The number of COREUs issued increased significantly during this period, rising from approximately 5000 messages per year before the Single European Act (1987) to 7500 around the end of the Cold War (1988-1990), and to more than 11,000 in 1991. The annual number of COREUs issued since 1991 has remained fairly constant, indicating a level of maturity in the foreign policy agenda that has been evident since the early 1990 s. $^{7}$ These changes took place over a relatively short period and inevitably created new expectations. Yet as pointed out by Christopher Hill (1993), in terms of actual capabilities rather little had changed from the 1980s. While his analysis applied to military capability and institutional structures, it could also be extended to information-processing capability: despite the member states having increased their exchange of information, they were doing little in terms of information analysis and long-term planning.

The end of the Cold War provided the momentum for discussions of a new form of cooperation on foreign policy within the framework of the Maastricht Treaty. The member states spent a significant amount of time debating its institutional structure. The future role of the European Commission, in particular, led to heated debate. It had, after all, played a leadership role in German reunification and in Western European relations with the Central and Eastern European countries. Some member states argued that it could now act as an expert bureaucracy to carry out much of the information analysis. Especially for smaller member states with limited resources this was an attractive option from the perspective of efficiency as well as credibility. As a supranational body, the Commission was expected to be less biased and more likely to provide analyses taking into account the broader European interest. Many member states, however, felt that the Commission had already exceeded its authority and that it was time to put it back in its box. A compromise was eventually reached that allowed the Commission to participate more fully in policy discussions (for example through the shared right of initiative), but at the same time recognized the subsidiary nature of its role compared with that of the member states. The Maastricht Treaty did not extend the information-processing capacity of the European Commission.

Despite some resentment towards these arrangements, Commission President Delors nevertheless pressed ahead by creating the position of Commissioner for External Political Relations with a supporting Directorate-General. However, these changes did not lead to an

5 The German Democratic Republic became part of the internal market and thus had to comply with the acquis communitaire.

6 The EU Troika consisted of the Presidency-in-office as well as the preceding and succeeding presidencies. The administration in Mostar was part of an agreement between the Bosnian Croats and Muslims.

7 Information provided by the Council Secretariat. See also Smith (2004) and Bicchi (2010). 
increase in foreign policy analysis on the part of the Commission. In the absence of Commission initiatives, the leadership in CFSP after Maastricht thus stayed with the Presidency. From an informational perspective not much changed in comparison to EPC. The cooperation remained limited to information-sharing and the quality of the data depended entirely on what was provided by the individual member states. However, as European foreign policy in the post-1989 period became more complex, the Presidency increasingly began to look to at the Council Secretariat's CFSP unit for administrative support and informational input. ${ }^{8}$ As a body under the direct control of the member states, it was preferred over the European Commission (Dijkstra 2008, 2010). Although the Secretariat's CFSP unit was engaged in conceptual issues, it was far too small to process information adequately for the EU. Furthermore, it had to rely on information supplied by the member states, because it did not have the capacity to gather information on its own. The continuing problems in Bosnia, and the fact that the United States finally became involved in bringing the conflict to an end, showed the limits of such institutional structures. It created the necessary momentum for the Amsterdam Treaty (1997) to establish a real analytical capacity in Brussels.

\section{The Gathering and Processing of Information after the Amsterdam Treaty}

The agenda of the Amsterdam Treaty was prepared by the Reflection Group, which consisted of national representatives under the chairmanship of Carlos Westendorp (June-December 1995). The Group met in parallel with the American-led Dayton process, and it is thus hardly surprising that its report urged the member states to 'find ways and means of providing the Union with a greater capacity for external action'. For this purpose, the report suggested improvements to the CFSP policy cycle. In order to prepare decisions, the report noted 'that an analysis, forecasting, early warning system and planning unit should be set up'. Such a unit could ensure 'the necessary followup to crisis situations' and could prepare 'possible response and decision options'. The unit 'could, moreover, encourage a common vision and greater cooperation among the member states. The latter and the Commission should in the unit share the information they possess so that correct analyses of the situations may be done' (para 153). This body eventually became the Policy Planning and Early Warning Unit (the Policy Unit), and was located within the Council Secretariat. ${ }^{9}$

The Policy Unit worked for the High Representative for the CFSP, a new post created by the Treaty as well, and occupied by Javier Solana (1999-2009). It consisted of one seconded national official per member state and civil servants drawn from the Council Secretariat, the European Commission and the Western European Union adding up to approximately 35 civil servants. ${ }^{10}$ Its main function was to analyse information shared by the member states on topics of direct relevance to CFSP. However, the responsibility for analysing information in the Council Secretariat was extended beyond the Policy Unit. The Directorate-General of External Relations (DG E) grew substantially and its analytical functions became more extensive. In order to increase coherence and reduce bureaucratic rivalry, some parts of the Policy Unit were actually integrated into this Directorate, leading to a nucleus of a European foreign service consisting of approximately 200 civil servants (Duke and Vanhoonacker 2006).

In addition to these bureaucracies for analysis, the Amsterdam Treaty also provided the Council Secretariat with some limited information-gathering capabilities, particularly through the establishment of European Union Special Representatives (EUSRs). While the EUSRs constitute a diverse group that includes both Brussels-based envoys and locally-based representatives, they have been described as the 'ears and eyes' of the High Representative and the member states in a number of conflict regions relevant to European foreign policy. They were no substitute for a proper foreign

8 The EPC Secretariat was integrated into the Council Secretariat and became the CFSP unit.

9 When the EEAS will become operational, the Policy Unit will be integrated in this new service.

10 The Western European Union previously constituted the defence arm of the European Union. 
service, but they were appointed at Director-General level, which gave them high-level access to officials from third countries. Their support staffs, consisting of a few seconded national officials, reported extensively to the relevant units in the Council Secretariat (Grevi 2007). Several 'doublehatting' agreements, where a EUSR also had an important United Nations function, such as in Bosnia and Kosovo, gave them significant authority and unrivalled information-gathering resources of great benefit to the Council Secretariat.

In parallel with these developments in the Council Secretariat, the services of the European Commission itself also professionalised after the Amsterdam Treaty. Under the leadership of the External Relations Commissioner Chris Patten (1999-2004), the Commission focused on improving its systems of implementation and delivery, which gave the member states and the Council Secretariat greater freedom to focus on analysis and decision-making (Spence 2006). The Commission delegations in third countries also underwent reform. The Commission, for example, opened various delegations in non-ACP countries, thereby stressing its political role, and bringing the total number of these delegations to 130 (Bruter 1999). It ended the distinction between staff based in Brussels and those based in the delegations and made career progression dependent on experience in the latter. The number of A-grade officials in the Commission delegations, as a result, increased from 165 to 440 (Spence 2004). Although the delegations received a formal function to report on the situation on the ground (Duke 2002), in practice diplomatic reporting (and thus autonomous information-gathering) remained somewhat limited (Bruter 1999). This was reflected in the still relatively low number of COREUs that originated from the Commission (f.e. 2.8 per cent of the total in 2008). ${ }^{11}$

Although the way in which member states gather and process information changed in the CFSP following the Amsterdam Treaty, the most important developments resulted from the creation of the European Security and Defence Policy (ESDP, 1999-present) (Christiansen and Vanhoonacker 2008; Dijkstra 2008, 2010). Previously, informational complexity had been somewhat limited in European foreign policy-making. Common declarations, coordinated positions and occasional démarches in third countries did not require any extensive collection or analysis of information. The most complex cases were generally those relating to boundary dossiers, such as occurred during the reunification of Germany. In those dossiers the Commission provided much of the informational input. However, when the member states started to engage in common initiatives to send peacekeepers across the globe, the informational complexities increased and a demand for readily-available high-quality information emerged. The member states very quickly established various bodies within the Council Secretariat for analysing information. These were the EU Military Staff (EUMS), the Civilian Planning and Conduct Capability (CPCC) and the Crisis Management and Planning Directorate (CMPD), employing up to 400 A-grade officials. Their wide-ranging duties included issuing early warning reports, military strategic options, and monitoring ongoing operations. For more secretive work, the member states have established an Intelligence Division (INTDEV) and a Situation Centre (SITCEN) in charge of risk assessments for joint actions (Duke 2006).

Simultaneously a range of information-gathering capabilities were also established within the framework of the ESDP. Before agreeing to a joint operation, member states generally first send a fact-finding mission to gather information or they establish a planning team on the ground. These teams consist of members of the Council Secretariat staff and they report via the High Representative to the member states. While these missions are created on an ad hoc basis and require the permission of the member states' ambassadors before they can take place, there are a growing number of instances where civil servants tour around third states before the member states formally state that EU action is appropriate - particularly where there is a need for a rapid deployment. Not only do fact-finding missions challenge the member states' role as gatekeepers of information, but their reports often form important input for draft decision-making documents. The

11 Information provided by Council Secretariat. 
Crisis Management Concept, which discusses general political questions such as the level of military presence, the mandate and the duration of joint action, draws on these fact-finding missions (interviews Council Secretariat officials, 2009). After Amsterdam information in the ESDP thus increasingly became gathered through autonomous channels.

Finally, information is also gathered continuously during ESDP operations. Depending on the difficulty of the mission, the force commander or head of mission on the ground sends daily, weekly and/or monthly reports to the member states and the Council Secretariat in Brussels. In the Council working groups, the member states can discuss points of relevance that are of interest to them in the written reports and can request further information, although in most cases much discretion is left to those in the field and micro-management from Brussels is rare (interviews national officials, 2009). Senior personnel from the field sometimes brief the member states in the various Council bodies in person, which is then followed by an exchange of views. At the same time, missions are permanently monitored from the Operational Headquarters (at NATO and in selected lead-nation member states) or from Brussels in the case of civilian missions. These bodies also provide the member states with up-to-date information. Needless to say, many member states continue their own information-gathering efforts in countries with ESDP operations through their embassies and national intelligence officers. National contingents also often send information directly to their national capitals notwithstanding the formal chain of command. The point, however, is that the operations, the headquarters and the bureaucratic bodies in Brussels no longer fully rely on the member states for their information.

The Amsterdam Treaty constitutes a major breakthrough in terms of cooperation. For the first time, the member states moved beyond information-sharing and established modest Europeanlevel bodies both to process and gather information. The creation of new players such as the Policy Unit, the EUSRs, SITCEN and the EUMS can be seen as the direct consequence of the EU's ambition to develop an operational European foreign policy. Sending troops and police officers abroad considerably raised the informational quality standards and brought new challenges in terms of efficiency. An informational system entirely based on the voluntary contributions of its member states was not only too slow, it also lacked reliability and credibility. While recognising the need to delegate information tasks to the European level, national ministries of foreign affairs nevertheless still maintained an important degree of control. They entrusted the new tasks to the Council Secretariat rather than to the European Commission and staffed the units with a majority of seconded national diplomats. The input of the Commission and its external delegations was not sufficiently integrated and the heavy reliance on seconded national diplomats sustained the old problem of sender-biased information.

The Lisbon Treaty is the most recent attempt to address some of these limitations and further strengthens the European-level capabilities of information-gathering and processing. The External Action Service has the potential to provide the Union with the long-awaited Brussels expert bureaucracy. By bringing together civil servants from the member states, the Commission and the Council Secretariat and by creating single geographical and thematic desks, it bundles information previously scattered over different institutions (Avery et al. 2007; Kurpas et al. 2007). With an eventual composition of several thousand diplomats, civil servants and military staff, the EEAS will considerably expand the Union's capacities for autonomous analysis. The 130 Union delegations directly reporting to the High Representative and the EEAS will furthermore significantly increase the pool of data to be processed. In addition, the scope of information will take account of all dimensions of EU external relations including trade, development and CFSP. The consequences are also important. There is a serious chance that the Brussels-based foreign policy administration may develop a strong informational surpluses vis-à-vis the member states. Although it may still take some time before the new machinery is fully operational, it is likely that in the long term this will have an impact on the European foreign policy process. 


\section{Conclusions}

The gathering and processing of foreign policy information was traditionally an activity of states performed by ministries of foreign affairs and embassies. Due to the strong notion of 'self-help', information-sharing was limited and mainly organised bilaterally with low levels of institutionalisation. After the Second World War, there was an increasing tendency to share information within multilateral and regional organisations, but here also the flows of information depended to a large extent on what the member states were willing to share (Stone 2009). If in certain cases, such as that of the International Atomic Energy Agency (IAEA), the organisation carried out its own fact-finding, the process of information-gathering and processing was mostly confined to a limited number of issue areas and did not deal with foreign policy in its entirety. Foreign policy coordination in the context of the European Union thus constitutes an important break with previous practice, in that the multilateral exchange of foreign policy information is highly institutionalised and has a broad scope that covers most aspects of foreign policy. The member states have furthermore established bodies in Brussels for analysing information to support their decisions and actions, and have even created a limited number of information-gathering channels. The Lisbon Treaty and the creation of the EEAS further expand the capacities for autonomous information gathering and processing.

The development of a European system of mere information sharing into one of autonomous information-gathering and processing has taken a long time and has been difficult. For almost 30 years, the member states maintained firm control of their own capabilities for gathering and analysing information, thereby maintaining the maximum possible control over information flows. The national capitals were thus the centres of informational gravity rather than Brussels. Yet the end of the Cold War and the development of a role for the EU in crisis management demanded a greater degree of continuity, together with a more medium and long-term approach, and new requirements in terms of the quality and speed of delivery of information. The ad hoc character of the information flow provided by the member states increasingly conflicted with the functional need for efficiency. Decisions to engage in military or civilian operations furthermore required permanent bodies that could provide the much needed common analysis of foreign policy problems. Gradually, information-related tasks were delegated to the Brussels-based institutions, culminating into the creation of the EEAS.

This article is a first attempt to describe and explain the development of the European Union from a platform to share foreign policy information into an actor that gathers and processes information autonomously. The study of European foreign policy from an 'information viewpoint' is not merely interesting from an historical perspective. A more in-depth study of information flows, both in quantitative and qualitative terms, and how they are translated into influence, could shed new light on the EU foreign policy-making process in general. The EEAS as a new centre of foreign policy expertise provides us with interesting new empirical material to investigate to which extent informational asymmetries lead to an advantage in policy-making. Answering these questions would greatly benefit our understanding of the dynamics of European foreign policymaking.

\section{References}

Abbot, K., and D. Snidal. 1998. Why states act through formal international organizations. Journal of Conflict Resolution 42, no. 1: 3-32.

Allen, D. 1998. Who speaks for Europe? The search for an effective and coherent foreign policy. In A common foreign policy for Europe? Competing visions of the CFSP, ed. J. Peterson, and H. 
Sjursen, 41-58. London: Routledge.

Arrow, K. 1985. The economics of agency. In Principals and agents: the structure of business, ed. J. Pratt, and R. Zeckhauser, 36-51. Cambridge: Harvard Business School Press.

Avery, G. et al. 2007. The EU Foreign Service: how to build a more effective common policy, EPC Working Paper, 28.

Betts, R. 2002. Fixing intelligence. Foreign Affairs 81, no. 1: 43-59.

Bicchi, F. 2010. Still 'national' preferences? The circulation of information in EU foreign policy and preference formation. Paper presented at Eurotrans workshop of ARENA, 7-8 October, in Oslo.

Bodenheimer, S. 1967. Political Union: a microcosm of European politics, 1960-66. Leiden: A.W. Sijthoff.

Bruter, M. 1999. Diplomacy without a state: the external delegations of the European Commission. Journal of European Public Policy 6, no. 2: 183-205.

Bull, H. 1977. The anarchical society: a study of order in world politics. Basingstoke: Macmillan.

Christiansen, T., and S. Vanhoonacker. 2008. At a critical juncture? Change and continuity in the institutional development of the Council Secretariat. West European Politics 31, no. 4: 751-70.

Crawford, V., and J. Sobel. 1982. Strategic information transmission. Econometrica 50, no. 6: 1431-51.

De Schoutheete, P. 1986. La cooperation politique européenne. Brussels: Labor.

Dijkstra, H. 2008. The Council Secretariat's role in the common foreign and security policy. European Foreign Affairs Review 13, no. 2: 149-66.

Dijkstra, H. 2010. Explaining variation in the role of the EU Council Secretariat in first and second pillar policy-making. Journal of European Public Policy 17, no. 4: 527-44.

Downs, G., and D. Rocke. 1994. Conflict, agency, and gambling for resurrection: the principalagent problem goes to war. American Journal of Political Science 38, no. 2: 362-80.

Duke, S. 2002. Preparing for European diplomacy? Journal of Common Market Studies 40, no. 5: 849-70.

Duke, S. 2006. Intelligence, security and information flows in CFSP. Intelligence and National Security 21, no. 4: 604-30.

Duke, S., and S. Vanhoonacker. 2006. Administrative governance in the CFSP: development and practice. European Foreign Affairs Review 11, no. 2: 163-82.

Epstein, D., and S. O'Halloran. 1999. Delegating powers: a transaction cost politics approach to policy making under separate powers. Cambridge: Cambridge University Press. 
Fursdon, E. 1980. The European defence community: a history. London: Macmillan.

George, A. 1980. Presidential decisionmaking in foreign policy: the effective use of information and advice. Boulder: Westview Press.

Grevi, G. 2007. Pioneering foreign policy: the EU special representatives. Chaillot Papers, 106.

Hawkins, D., D. Lake. D. Nielsen, and M. Tierney. 2006. Delegation and agency in international organizations. Cambridge: Cambridge University Press.

Hill, C. 1993. The capability-expectations gap, or conceptualizing Europe's international role. Journal of Common Market Studies 31, no. 3: 305-28.

Hill, C. 1998. Closing the capabilities-expectations gap? In A common foreign policy for Europe? Competing visions of the CFSP, ed. J. Peterson, and H. Sjursen, 18-38. London: Routledge.

Hill, C. 2003. The changing of foreign policy. Basingstoke: Palgrave Macmillan.

Hocking, B. 1999. Foreign ministries: change and adaptation. Basingstoke: Macmillan.

Hoffmann, S. 1966. Obstinate or obsolete? The fate of the nation-state and the case of western Europe. Daedalus 95, no. 3: 862-915.

Keohane, R. 1984. After hegemony: cooperation and discord in the world political economy. Princeton: Princeton University Press.

Kissinger, H. 1995. Diplomacy. London: Simon and Schuster.

Kupchan, C., and C. Kupchan. 1991. Concerts, collective security, and the future of Europe. International Security 16, no. 1: 114-61.

Kurpas, S. et al. 2007. The Treaty of Lisbon: implementing the institutional innovations. Brussels: Egmont.

Miller, G. 2005. The political evolution of principal-agent models. Annual Review of Political Science 8: 203-25.

Milner, H. 1997. Interests, institutions and information: domestic politics and international relations. Princeton: Princeton University Press.

Milner, H., and A. Moravcsik. 2009. Power, interdependence, and nonstate actors in world politics. Princeton: Princeton University Press.

Müller-Brandeck-Bocquet, G. 2002. The new CFSP and ESDP decision-making system of the European Union. European Foreign Affairs Review 7, no. 3: 257-82.

Müller-Wille, B. 2008. The effect of international terrorism on EU intelligence cooperation. Journal of Common Market Studies 46, no. 1: 49-73.

Nuttall, S. 1992. European political co-operation. Oxford: Clarendon Press. 
Nuttall, S. 2000. European foreign policy. Oxford: Oxford University Press.

Pollack, M. 2003. The engines of European integration: delegation, agency and agenda-setting. Oxford: Oxford University Press.

Rayner, L. 2005. The EU Foreign Ministry and Union Embassies. London: The Foreign Policy Centre.

Richelson, J. 1990. The calculus of intelligence co-operation. International Journal of Intelligence and Counterintelligence 4, no. 3: 307-23.

Smith, M.E. 2004. Europe's foreign and security policy: the institutionalization of cooperation. Cambridge: Cambridge University Press.

Spence, D. 2004. The European Commission's External Service. Public Policy and Administration 19, no. 3: 61-76.

Spence, D. 2006. The commission and the common foreign and security policy. In The European Commission, ed. D. Spence, and G. Edwards, 356-95. London: John Harper.

Stone, R. 2009. Institutions, power, and interdependence. In Power, interdependence, and nonstate actors in world politics, ed. H. Milner, and A. Moravcsik, 31-49. Princeton: Princeton University Press.

Tonra, B. 2003. Constructing the common foreign and security policy: the utility of a cognitive approach. Journal of Common Market Studies 41, no. 4: 731-56.

Vanhoonacker, S., H. Dijkstra, and H. Maurer. 2010. Understanding the role of bureaucracy in the European security and defence policy: the state of the art. European Integration online Papers 14: $1-33$.

Vertzberger, Y. 1990. The world in their minds: information processing, cognition, and perception in foreign policy decision-making. Stanford: Stanford University Press.

Walsh, J. 2006. Intelligence-sharing in the European Union: institutions are not enough. Journal of Common Market Studies 44, no. 3: 625-43.

Warner, M. 2002. Wanted: a definition of intelligence. Studies in Intelligence 46, no. 3: 15-22.

Watson, A. 1982. Diplomacy: the dialogue between states. London: Methuen. 